\title{
MRI 検査業務における妊娠就業者の配置方針の背景要因の検討
}

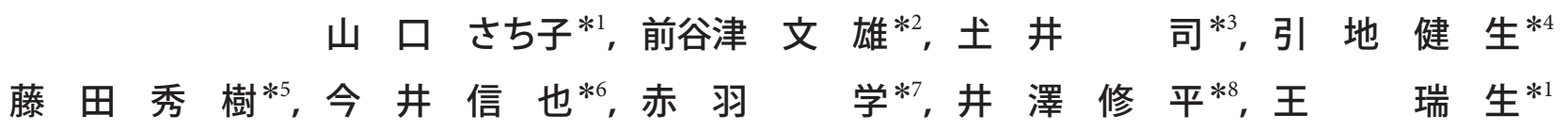

本研究では 2017 年 11 月にMRI検査責任者宛てに実施した妊娠就業者の MRI検查業務の配置方針に関する アンケート 2072 件について, 消極的配置（妊娠報告後は配置を減らす, 配置しない等）の背景要因を検討した. 背景要因として，回答者の非電離放射線の見解と身体負荷の見解に着目した。第一に，決定木分析で消極的配 置の回答について段階的に分析を行った結果, 第一〜三層で非電離放射線や身体負荷の見解が要因として抽出 され，特に有害性に対する懸念が強く影響していた。続いて，消極的配置の選択に扔ける非電離放射線／身体 負荷の見解の影響を二項ロジスティック回帰分析で検討した。独立変数は単変量解析で有意差を示した非電離 放射線の「関心・知識取得状況」,「有害性の懸念」,「ばく露防護」の3 項目に, 「身体負荷」「基本属性」(性別, 年齢，人員充足度）とした．その結果，消極的配置の選択においては，非電離放射線への興味・関心は選択に 影響を及ぼさないが，有害性やばく露防護に対する憂慮が影響を与えていることが示された．身体負荷の見解 についても影響が観察されたことから，配置方針を検討する際の考慮要素であることが示唆された．また，基 本属性では特に年齢が選択に影響していることが明らかとなった．本研究の分析結果は管理者と当事者が同程 度に安全情報を共有できる資料作りに活用予定である。

キーワード：非電離放射線，MRI，安全意識，妊娠就業者，業務配置

\section{1 はじめに}

非電離放射線は普遍的な物理因子であり,波長では 0.3 THz以下の電波や赤外線, 可視光線, 一部の紫外線な どの呼称である.これらは周波数に応じた短期的影響を 与元, 静磁界は力学的作用や神経刺激作用, 低周波領域 では神経刺激, 高周波領域では発熱が発生する ${ }^{1-3)}$ 。磁 気共鳴画像装置（MRI装置）は放射線科における主要 なイメージングモダリティで数テスラ(地磁気の数万倍) の静磁場とパルス磁場, 高周波電磁場といった非電離放 射線を多用する $\left.{ }^{4)}, 5\right)$ ．このため，MRI検査の安全性につ いては，短期的影響防護の観点から非電離放射線と騷音 について装置規格で出力制御がなされている4).

一方で, 妊娠時の MRI検査の適応は議論を要する課 題である.MRI装置で使用される非電離放射線のうち, 特に静磁場については出力制御ができないこともあり発 生・生殖への影響が懸念されてきた. 現在のところ明確 な影響の報告はない状況であり ${ }^{5.8)}$, 胎児MRI検査につ いては一定の知見が収集されている9（ただし，疫学研 究には継続性が求められている(10), 11) . しかしながら,

原稿受付 2018年11月 5 日 (Received date: November 5, 2018) 原稿受理 2019年 1 月 28日 (Accepted date: January 28, 2019)

J-STAGE Advance published date: February 19, 2019

*1 労働安全衛生総合研究所産業毒性・生体影響研究グループ

*2 公益財団法人宮城厚生協会泉病院放射線科

*3 社会医療法人高清会高井病院放射線科

$* 4$ 医療法人ひろせ会広瀨病院診療技術部放射線科

*5 社会福祉法人恩賜財団済生会支部大阪府済生会中津病院放射線技術 部

*6大阪物療大学保健医療学部

*7 奈良県立医科大学公衆衛生学講座

*8 労働安全衛生総合研究所産業ストレス研究グループ 連絡先：テ214-8585 神奈川県川崎市多摩区長尾 6-21-1 労働安全衛生総合研究所産業毒性・生体影響研究グループ 山口さ ち子

E-mail: yamaguchi@h.jniosh.johas.go.jp doi: 10.2486/josh.JOSH-2018-0016-GE
MRI検査業務に携わる就業者は強磁場に高頻度で日常 的にばく露される特殊環境での勤務となるため ${ }^{12)}$, 就業 者からは現在の安全性の知見の状況についてリスクが不 明であるとみなしている可能性がある.

このため, 本研究に先立ち実施した調査 ${ }^{13)}$ の計画立 案時の技師長職位者を交えた討議において, 妊娠就業者 のMRI 検査業務配置を考えるにあたり上記のような非 電離放射線の生体影響の見解に加え, 患者移乗やコイル セットなど身体負荷の見解が配置方針を判断要素である と予想した，そこで，調查票にはこれら非電離放射線／ 身体負荷の見解について尋ねることができる構成とし た。この調查票を用いて 2017 年 11 月に全国 5769施設宛 に妊娠就業者の MRI検査業務の配置方針とその選択根 拠を問うアンケートの郵送調査を実施した結果，妊娠就 業者の MRI検查配置の方針は施設ごとに異なっていた が，妊娠時にはMRI検査配置回数を減らす, 配置しな いなど回避傾向（消極的配置）は $52.6 \%$ 施設で示され $た^{13)}$. また，配置方針の選択根拠として非電離放射線に 対する念のための措置としてという回答が $57.6 \%$ で，リ スクが不明であるとみなされている可能性が示唆され た.

MRI装置使用者の静磁場や高周波電磁界ばく露によ る生体影響の知識取得機会に関しては, 従事者の多数を 占める診療放射線技師の授業カリキュラムでは十分に提 供はなされておらず，磁気共鳴専門技術者試験の受験に おいて習得機会がある。このため, 磁気共鳴専門技術者 （現在約 1000 人）であれば知識を有するものの，それ以 外のMRI従事者に対しては磁気共鳴専門技術者による 安全教育の実施か自身による情報収集が知識取得とな る.また，マニュアル等で明文化された組織的対策を有 するのは回答施設の $2.1 \%$ と非常に少数であった ${ }^{13)}$. こ 
のため, 就業者の妊娠時の MRI 検查業務配置について は判断者の知識や見解が反映されるのが現状であるにも 関わらず，管理者と当事者が同程度の安全性の見解をも って話し合いに臨むための科学的根拠の提示が十分なさ れていないことが課題である. 加えて妊娠時にはMRI 検査では身体動作への配慮もなされる．これらのことか ら, 非電離放射線/身体負荷の見解について科学的根拠 やそれらから想定されるリスクの考え方や具体的対応策 を整理し提案することは管理者及び当事者にとって根拠 を持った配置決定につながると期待される.

そこで本研究では 2017年11月に実施した妊娠就業者 のMRI検査業務の配置方針に関するアンケートについ て, 消極的配置の決定における非電離放射線/身体負荷 の見解の関与を明らかにすることを目的として背景要因 の解析を行った。本調查票の設問は (1)「基本属性（18 項目)」, (2)非電離 $/$ 身体負荷の見解や勤務上の状況に基 づく「選択根拠（15項目）」，(3)配置方針の決定後の具 体的対策を示す「実施内容 (3 項目)」, (4)「職場環境 (30 項目)」, (5)「将来対策 (6項目)」の5 項目に分類され, このうち, 「選択根拠」は, 配置方針の判断要素と予想 される非電離放射線/身体負荷の見解が含まれ最も関連 があると考えられる（表1）。このため第一に決定木分 析を行い, 分類木の上位に「選択根拠」が抽出されるか, また, その中でも非電離/身体負荷の見解がごの程度抽 出されるか確認した. 続いて, 消極的配置の選択に非電 離／身体負荷の見解が与える影響について二項ロジステ イック回帰分析にて検討した。

\section{2 方法}

\section{1）調査票の配布と回収}

調査内容及び方法は我々の先行研究で報告済みであ $る^{13)}$. 具体的には, 調查対象施設は日本医療画像システ ム白書の MRI設置施設一覧を元にリストを作成し, 宛 先は「MRI検查責任者」宛とした. 平成29年 11 月 7日 に上記リストの 5769 施設宛に発送し, 不達6件を除い た 5763 施設を総配布施設数とした. 調査票は「I 基本 情報」,「II 就業者の妊娠に関する一般的事項」,「III 妊娠中の MRI検査就業の方針」「 「MRI検査業務で考慮 する事項, 妊娠中の代替業務の考元方」,「IV 非電離 放射線全般に関する見解と, 妊娠中の MRI検查業務の 今後の方針」の 4 項目 34 問と「V 自由記述」より構成 した. 調査票は対象者が受領してから約 3 週間後を回答 期限とし, 回収された調査票は 2103 件で回収率は $36.5 \%$ あった. 回収した調査票から完全白票等の無効 回答を除いた 2072 件を有効回答とした. 回答者及び施 設特性は先行研究で記載のと打りである ${ }^{13)}$. 具体的には 男性 86.5\%, 女性 $13.2 \%$ で男性回答者が多く年代は 30 - 50 代回答者で $89.4 \%$ を占めていた ${ }^{13)}$.

\section{2）配置方針の分類とデータセット}

妊娠就業者の MRI検査業務の配置方針の単純集計結 果は弤娠を機に配置回数を増減するかを基準に, 積極的 配置 $(n=157)$, 現状維持 $(n=679)$, 消極的配置 $(n=1088)$
に分類した（数值は先行研究 ${ }^{13)}$ に基づく）. 消極的配置 はMRI 検査業務配置の忌避傾向を知るために従来の 3 回答（配置回数を少なくする $(\mathrm{n}=192)$, 可能な限り配 置しない $(\mathrm{n}=501)$, 配置しない $(\mathrm{n}=395))$ を1つに再 コーディングした. 本研究では消極的配置の選択に注目 するため，消極的配置を「1」，それ以外の回答を「0」 としたデータセットを以後解析として用いた.

\section{表 1 調查票の構成}

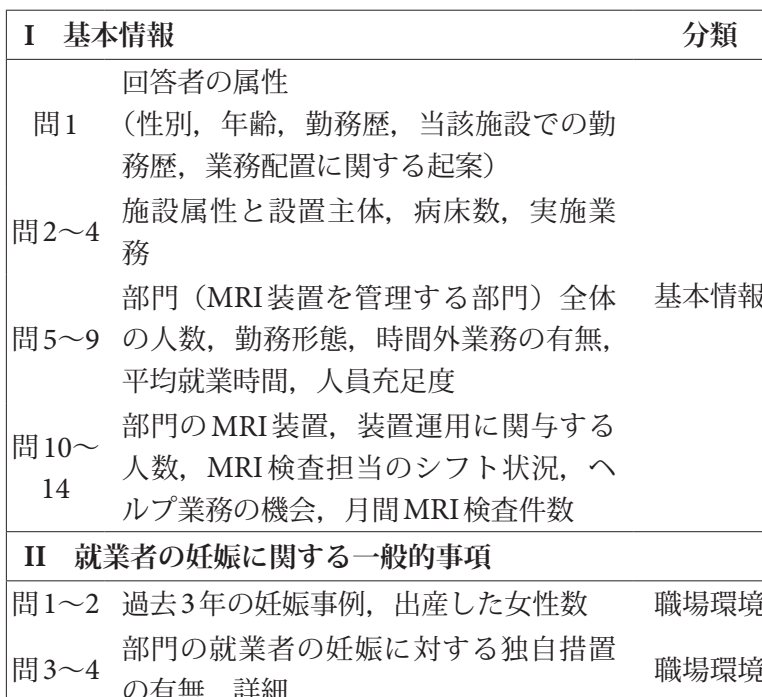

III 弤娠中の MRI 検查就業の方針, MRI検査 業務で考虑する事項, 弤娠中の代替業務の考え 方

妊娠中就業者の MRI 検査の配置の方針

問 1 （予定方針含む）

（方針の詳細，業務内容の変更の有無、実施内容 業務内容の変更内容とその時期）

問 1 の選択根拠

問2（MRI検查と生殖・発生への影響，漏洩 選択根拠 磁界，身体的負荷，勤務様態について）

問 3 4 問 1の実施方針，実際例 MRI検査業務で「生殖・発生への影響」

問 5 を考慮する際の情報提供ニーズについ て，内容及び優先順位 漏洩磁界中の一時的体調変化の認知状 況

職場環境

将来対策

選択根拠

MRI 検查業務で「一時的体調変化」を

問7 考慮する際の情報提供ニーズについて, 内容及び優先順位

問8 妊娠就業者への代替業務（予定方針含 む)

将来対策

職場環境

IV 非電離放射線全般に関する見解と, 妊娠中 のMRI 検查業務の今後の方針

\begin{tabular}{|c|c|c|}
\hline 問 1〜2 & $\begin{array}{l}\text { 非電離放射線に関する情報の取得状況 } \\
\text { とコメント }\end{array}$ & 選択根拠 \\
\hline 問 3 & 問 3-1の運用見込み & 将来対策 \\
\hline 問 4 & ガイドライン・ガイダンスのニーズ & 将来対策 \\
\hline 問 5 & 海外の方針で施設実態に見合うもの & 将来対策 \\
\hline 問 6〜8 & $\begin{array}{l}\text { 安全教育の機会と頻度, 漏洩磁界の把 } \\
\text { 握状況, 安全性情報の入手先 }\end{array}$ & 職場環境 \\
\hline
\end{tabular}




\section{3）設問の分類}

設問の全体構成は表1のとおりである。このうち「選 択根拠」(表 1 III：問 2 及び問 $6, I V$ : 問 1) から非電離 ／身体負荷の見解に関する設問について, 本研究におけ る定義, 単純集計の結果 ${ }^{13)}$ を表2 示す. 本研究での解析 対象は典型回答のみとし, その他等自由記述を含む回答 については解析から除外した。

\section{ア）非電離放射線に対する考え方}

非電離放射線に対する考え方は, 設問立案時の構想か ら「関心・知識取得」,「有害性の懸念」,「ばく露防護」, MRI装置近辺での一時的体調変化の遭遇 ${ }^{14)}$, 15) に基づい た分類である「一時的体調変化」の 4 項目とした（表2）. 「関心・知識取得」は関心程度と安全情報の取得状況の 組み合わせから関心 (高), 関心 (低), 無関心と設定し
た.「その他」は各設問 $0.5 \%$ であったことから除外した. 「関心・知識取得」の対象は調査票本紙では 4 対象あるが, ここでは後程分析で使用した身のまわりの家電から発生 する非電離放射線の法令，ガイドラインに関する設問の 集計結果を示す。「有害性の懸念」は有害性の懸念なし, 念のための措置が必要, 有害性の懸念あり, 根拠でない, の 4 項目，「ばく露防護」は，容易，容易でない，根拠 でない,の3項目，「一時的体調変化」は遭遇あり機序 も理解, 遭遇あり機序は不明, 遭遇なし機序は理解, 遭 遇なし機序は不明，とした（表2）。

\section{イ）身体負荷の考え方}

患者移乗やコイルセットによる身体作業の対処を問う 身体負荷の考元方「身体負荷」は，身体負荷・低（低減 可), 身体負荷・高（低減不可）, 根拠でない，の3 項目

表2 非電離放射線及び身体負荷の見解に関する設問：単純集計結果と本研究における用語の定義

\begin{tabular}{|c|c|c|c|}
\hline 調查票 & 本研究での表記 & $\mathrm{n}$ & $\%$ \\
\hline 問＼cjkstart家電から発生する非電離放射線に関するガイドライン, 法令 & 「関心・知識取得」 & & \\
\hline 講演会を聞いたり, 自分で調べたことがある & 関心（高） & 160 & 7.7 \\
\hline 興味はあるが調べたり講演会に出たことはない & 関心（低） & 1424 & 68.7 \\
\hline 興味はない & 無関心 & 428 & 20.7 \\
\hline その他 & - & 10 & 0.5 \\
\hline 無効回答・無回答 & - & 50 & 2.4 \\
\hline 計 & - & 2072 & 100.0 \\
\hline 問ＭRI検查と生殖・発生への影響 & 「有害性の懸念」 & & \\
\hline これまでに生殖・発生への影響ありという報告はないため & 有害性の懸念なし & 455 & 22.0 \\
\hline $\begin{array}{l}\text { これまでに生殖・発生への影響ありという報告はないが, } \\
\text { 念のための措置として }\end{array}$ & 念のための措置が必要 & 1194 & 57.6 \\
\hline $\begin{array}{l}\text { これまでに生殖・発生への影響ありという報告を聞いたことが } \\
\text { あるため }\end{array}$ & 有害性の懸念あり & 80 & 3.9 \\
\hline この内容は担当方針の根拠ではない & 根拠でない & 227 & 11.0 \\
\hline その他 & （個別に解析） & 67 & 3.2 \\
\hline 無回答・無効回答 & - & 49 & 2.4 \\
\hline 計 & - & 2072 & 100.0 \\
\hline 問 MRI装置の漏洩磁界について & 「ばく露防護」 & & \\
\hline ばく露源からの防護が容易であるため & 容易 & 554 & 26.7 \\
\hline ばく露源からの防護が容易でないため & 容易でない & 481 & 23.2 \\
\hline この内容は担当方針の根拠ではない & 根拠でない & 884 & 42.7 \\
\hline その他 & （個別に解析） & 31 & 1.5 \\
\hline 無回答・無効回答 & - & 122 & 5.9 \\
\hline 計 & - & 2072 & 100.0 \\
\hline 問 一時的体調変化の遭遇 & 「一時的体調変化」 & & \\
\hline 事例に遭遇（伝聞含む）したことがある, 機序も知っている & 遭遇あり機序は理解 & 448 & 21.6 \\
\hline 事例に遭遇（伝聞含む）したことがある, 機序は知らない & 遭遇あり機序は不明 & 311 & 15.0 \\
\hline 事例に遭遇（伝聞含む）したことはない, 機序は知っている & 遭遇なし機序は理解 & 462 & 22.3 \\
\hline 事例に遭遇（伝聞含む）したことはない, 機序も知らない & 遭遇なし機序は不明 & 817 & 39.4 \\
\hline その他 & （個別に解析） & 11 & 0.5 \\
\hline 無回答・無効回答 & - & 23 & 1.1 \\
\hline 計 & - & 2072 & 100.0 \\
\hline 問 身体的負荷 & 「身体負荷」 & & \\
\hline $\begin{array}{l}\text { 介助などの身体負荷が少ないため } \\
\text { 又は低減する工夫や人員配置が可能であるため }\end{array}$ & $\begin{array}{l}\text { 身体負荷・低 } \\
\text { (低減可) }\end{array}$ & 808 & 39.0 \\
\hline 介助などの身体負荷が高いため & 身体負荷・高 & 542 & 26.2 \\
\hline 又は低減することができないため & （低減不可） & & \\
\hline この内容は担当方針の根拠ではない & 根拠でない & 569 & 27.5 \\
\hline その他 & （個別に解析） & 39 & 1.9 \\
\hline 無回答・無効回答 & - & 114 & 5.5 \\
\hline 計 & - & 2072 & 100.0 \\
\hline
\end{tabular}

Vol. 12, No. 1, pp. 3-12, (2019) 
とした（表2）.

\section{4) 決定木分析}

消極的配置の選択に影響を与える要因を探索するた め, 消極的配置の回答有無を従属変数とした決定木分析 を実施した．第一段階として表1の「基本属性」と「選 択根拠」を独立変数としたモデル, 第二段階として第一 段階に「作業環境」の項目を投入したモデル，最終段階 として全ての項目を投入したモデルで分析を行った. 第 一段階で投入した独立変数は 33 , 第二段階では 63 , 第 三段階では72であった. 分析は CHAID (CHi-square Automatic Interaction Detection）法により実施した. 各モデルに強く影響を与える要因の探索を目的とするた め, 有意水準は $1 \%$ 水準, 最大深度を 3 , 分析前の群（親 ノード）の最小の事例数を 100 , 分析後の群（子ノード） の最小の事例数を 50 と定めた. モデルの検証は 10 重交 差検証を行った. なお, 久損值は分析ソフトウェアの仕 様により単一カテゴリーとして扱われた.

\section{5）消極的配置の選択における非電離／身体負荷の影響 の検討}

分類木の上位に非電離 $/$ 身体負荷の見解が要因として 抽出されることを確認したため, 続いて消極的配置の選 択における非電離／身体負荷の見解との影響を二項ロジ スティック回帰分析にて検討した. 第一に消極的配置と 非電離／身体負荷の見解（表2）と「基本属性」でクロ 又集計を行い，カイ二乗検定で独立性の検定を行った. ここで有意差が得られなかった要因は除外し, 残りの項 目を独立変数とした. 消極的配置の回答有無を従属変数 として, 全独立変数を強制投入項として二項ロジスティ ック回帰分析を行った.

\section{6）統計解析}

統計ソフトはSPSS statistics 22 を使用し, Advanced statistics, Regressions, Decision Treeのモジュールを 使用した. 統計的有意差は $p<0.05$ とし, 決定木分析の み $p<0.01$ とした。

\section{3 結果}

\section{1 決定木分析による回答背景の分類}

消極的配置の選択に影響を与える要因を探索するため 決定木分析を実施した。図1にCHAIDによって生成さ れた決定木を示す。決定木分析は三段階に分けて実施し たが, 消極的配置の正分類率は 90.7-92.7\%, 全体で $81.2 \%-81.3 \%$ であった.

図 $1 \mathrm{~A}$ に第一段階の結果を示す。「基本属性」は要因 として抽出されず，全て「選択根拠」に基づく項目が抽 出された. 第一層は「有害性の懸念」の懸念で3つに分 岐し, そのうち有害性の懸念あり, 念のための措置が必 要という回答者は第二層で被ばくの有無で分岐した後, いずれも第三層で「身体負荷」が要因として抽出された. また, 第一層で, 有害性の懸念なしという回答者は第二 層で「ばく露防護」が抽出され, 容易でないという回答 者は最終ノードとなったが, それ以外の回答者は第三層 で「身体負荷」が要因として抽出された。第一層で「根
拠でない」の回答者は第二層で被ばくの有無で分岐した 後，第三層で「興味・関心」が抽出された.

図 $1 \mathrm{~B}$ に第二段階の結果を示す。第二段階と第三段階 は同じ結果が抽出された.第一段階と同じく第一層は「有 害性の懸念」で3つに分岐し，そのうち根拠でないとい う回答以外は第一段階と同じ要因，分岐であった．第一 段階で根拠でないという回答者は第二段階で当該施設で の実際例が要因として抽出され，第三層で勤務様態を配 置決定の根拠とするか否かが要因として抽出された.

これらの結果から，第一段階から第三段階まで分類木 で上位に表れる要因に調査票立案時に着目した非電離放 射線／身体負荷の見解が抽出されることを確認した。 た, 決定木分析では従属変数に対して影響の強い順に分 岐されることから ${ }^{16)}$, 配置方針の決定において非電離放 射線やの見解, 特に有害性に対する懸念が強く影響して いることが示された.

\section{2 消極的配置の選択と非電離放射線／身体負荷の影響}

図 1 で分類木上位に表れる要因に非電離放射線／身体 負荷の見解が抽出されたことから, 各項目（表2）の影 響を明らかにするため二項ロジスティック回帰分析を行 った. なお，図1において「選択根拠」であっても被ば くの有無がいずれの段階においても第二層に現れたが, 本研究では非電離放射線／身体負荷の見解が消極的配置 の選択に与える影響について注目するため, この要因に ついては解析に含めなかった.

ロジスティック回帰分析に先立ち，消極的配置の選択 と独立変数（表 2 及び「基本属性」）についてクロス集 計を行い力イ二乗検定で独立性の検定を行った。その結 果，表 2 にいては「一時的体調変化」以外全て有意差 を示した（ $\chi^{2}$ 検定, $\mathrm{df}=4$ 又は 6 , 各 $\left.p<0.0001\right)$.「基本属 性」については, 性別 $(\mathrm{df}=1, p<0.0001)$, 年齢 $(\mathrm{df}=4$, $p<0.01)$, 人員充足度 $(\mathrm{df}=2, p<0.05)$ が有意差を示した. これらカイ二乗検定で有意差を示した項目を独立変数と して投入した. モデル係数のオムニバス検定は $0.1 \%$ 水 準で有意となり，回帰式の有意性が保証される結果が得 られた。判別的中率は消極的配置で $91.2 \%$, 全体で $80.2 \%$ であった.

表 3 に消極的配置の選択を従属变数とした二項ロジス ティック回帰分析結果を示す。決定木分析で部分的に抽 出された非電離放射線の「興味・知識取得」は選択に影 響を及ぼしていなかった。一方で，分類木第一層で抽出 された「有害性の懸念」は選択に強く影響を与えており, 懸念の有無によって選択の指向性が明確に分かれていた （有害性の懸念なし：OR：0.081, 95\%CI:0.045-0.145, $p<0.0001$ 念のための措置が必要; OR : 4.491, 95\%CI : $2.970-6.791$, 有害性の懸念あり; OR：5.213, 95\%CI : $2.416-11.250$, 各 $p<0.0001)$.「ばく露」防護について も同様に回答内容による選択の指向性が異なっていた が, 有意差は容易でないという回答者のみで観察された (OR : 2.132, 95\%CI : 1.447-3.143, p<0.0001). 身体 負荷についても同様の傾向であったが,身体負荷低い(低 
A)

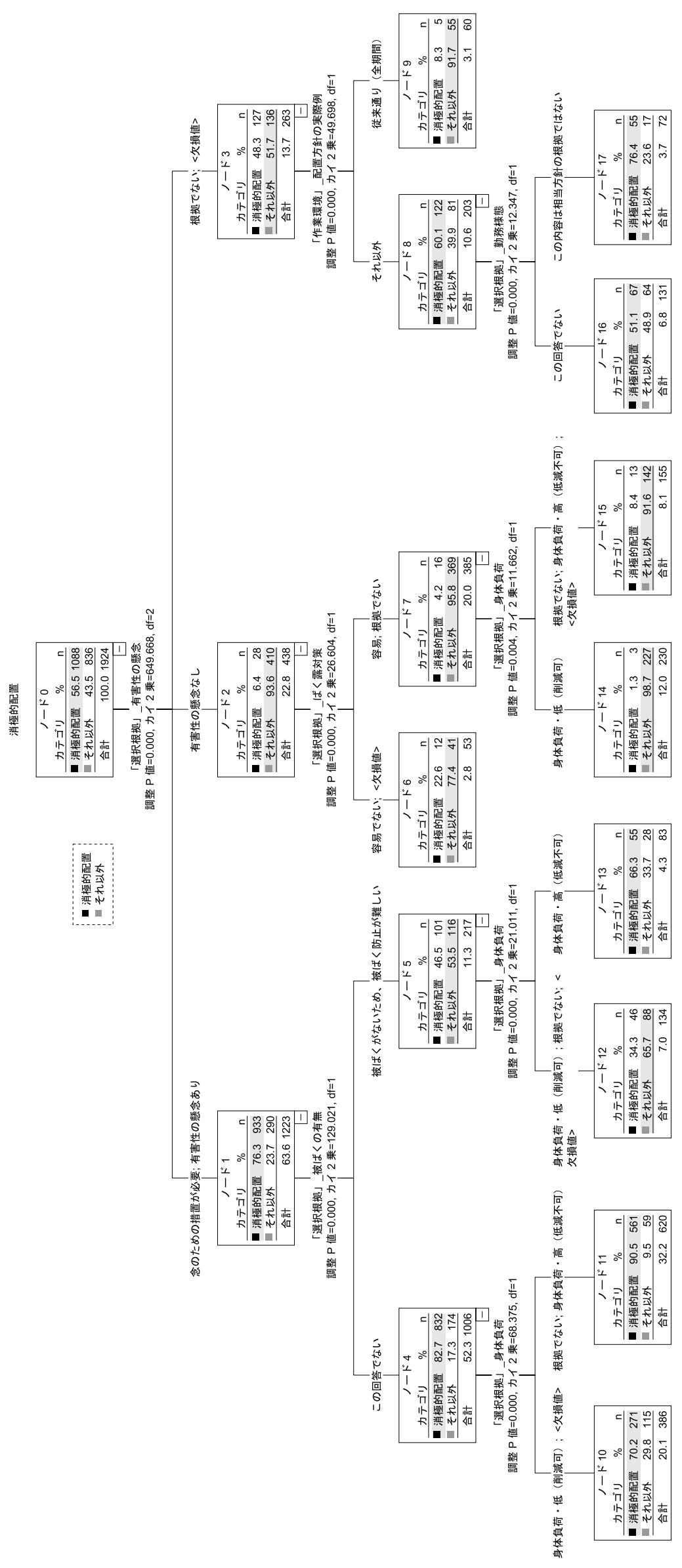


B)

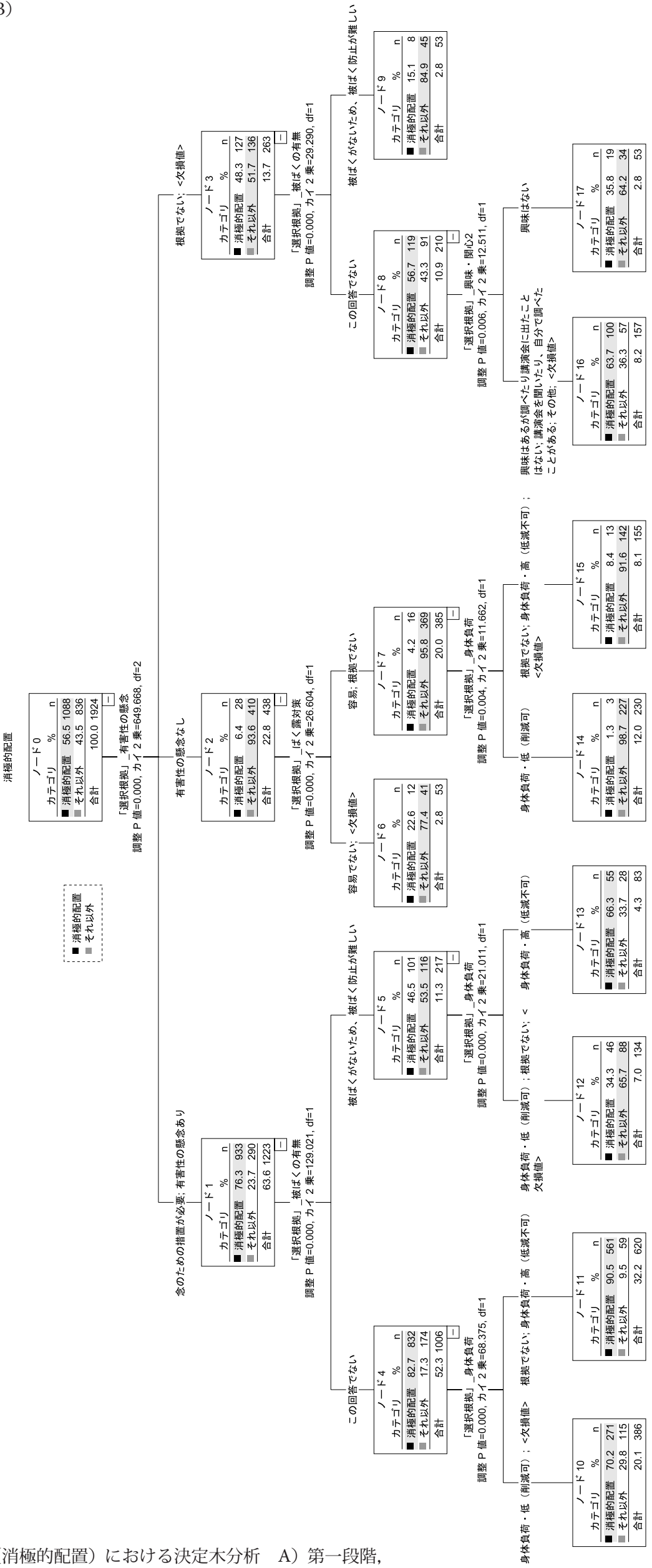

図 1 配置方針（消極的配置）における決定木分析 A) 第一段階,

B）第二段階. 第三段階は第二段階と同じ結果が表示された. 
減可）の回答者は消極的配置を有意に控えていた（OR： $0.291 ， 95 \% \mathrm{CI}: 0.202-0.416, p<0.0001)$. 基本属性 では年齢と人員充足度で有意差が観察され，年齢ついて は高齢回答者ほど保守的選択をしていた（60歳以上； OR : $2.335,95 \% \mathrm{CI}: 1.005-5.426,50-59$ 歳; OR : 2.253, 95\%CI：1.211-4.194，40-49歳; OR：1.852, $95 \% \mathrm{CI}: 1.013-3.383$, 各 $p<0.05)$. 人員充足度につい ては, 人員が充足している, 又は不足が軽度である回答 者は消極的配置の選択を控えていた（やや不足：OR： $0.609,95 \% \mathrm{CI}: 0.383-0.968, \quad p<0.05)$.

表3 消極的配置の選択に関する二項ロジスティック回帰分
析結果

\begin{tabular}{|c|c|c|c|}
\hline \multicolumn{4}{|c|}{ 消極的配置 } \\
\hline & OR & 95\% 信頼区間 & $\begin{array}{c}\text { 有意確率 } \\
(P)\end{array}$ \\
\hline \multicolumn{4}{|c|}{ 「関心・知識取得」 } \\
\hline 関心（高） & 1.082 & $(0.630,1.861)$ & 0.775 \\
\hline 関心（低） & 1.296 & $(0.788,2.131)$ & 0.306 \\
\hline 無関心 & \multicolumn{3}{|l|}{ Ref. } \\
\hline \multicolumn{4}{|c|}{ 「有害性の懸念」 } \\
\hline 有害性の懸念なし & 0.081 & $(0.045,0.145)$ & 0.000 \\
\hline 念のための措置 & 4.491 & $(2.970,6.791)$ & 0.000 \\
\hline 有害性の懸念あり & 5.213 & $(2.416,11.250)$ & 0.000 \\
\hline 根拠でない & \multicolumn{3}{|l|}{ Ref. } \\
\hline \multicolumn{4}{|c|}{ 「ばく露防護」 } \\
\hline 容易 & 0.978 & $(0.692,1.381)$ & 0.898 \\
\hline 容易でない & 2.132 & $(1.447,3.143)$ & 0.000 \\
\hline 根拠でない & \multicolumn{3}{|l|}{ Ref. } \\
\hline \multicolumn{4}{|c|}{ 「身体負荷」 } \\
\hline $\begin{array}{l}\text { 身体負荷低い } \\
\text { (低減可) }\end{array}$ & 0.290 & $(0.202,0.416)$ & 0.000 \\
\hline $\begin{array}{l}\text { 身体負荷高い } \\
\text { (低減不可) }\end{array}$ & 1.211 & $(0.816,1.795)$ & 0.342 \\
\hline 根拠でない & \multicolumn{3}{|l|}{ Ref. } \\
\hline \multicolumn{4}{|c|}{ 「性別」 } \\
\hline 男性 & 1.454 & $(0.987,2.142)$ & 0.059 \\
\hline 女性 & \multicolumn{3}{|l|}{ Ref. } \\
\hline \multicolumn{4}{|c|}{ 「年齢」 } \\
\hline 60 代以上 & 2.335 & $(1.005,5.426)$ & 0.049 \\
\hline 50 代 & 2.253 & $(1.211,4.194)$ & 0.010 \\
\hline 40 代 & 1.852 & $(1.013,3.383)$ & 0.045 \\
\hline 30 代 & 1.605 & $(0.867,2.971)$ & 0.132 \\
\hline 20 代 & \multicolumn{3}{|l|}{ Ref. } \\
\hline \multicolumn{4}{|c|}{ 「人員充足度」 } \\
\hline 十分である & 0.646 & $(0.412,1.016)$ & 0.058 \\
\hline やや不足 & 0.609 & $(0.383,0.968)$ & 0.036 \\
\hline 不足 & Ref. & & \\
\hline
\end{tabular}

これらの結果から, 消極的配置の選択においては非電 離放射線への興味・関心は選択に影響を及ぼさないが, 有害性やばく露防護に対する憂慮が影響を与えているこ とが示された. 身体負荷の見解についても影響が観察さ れたことから，配置方針を検討する際の考慮要素である ことが示唆された．また，基本属性では特に年齢が選択 に影響していることが明らかとなった。

\section{4 考察}

本研究は国内 MRI検查施設の MRI検查責任者宛に調 查票を発送して抢り，放射線科の技師長，装置責任者な ぞ注釈を加えているものの, その全てがMRI検査に詳 らかな回答者に行き渡ったかについてや, 複数名での回 答の可能性について除外できない. しかしながら，MRI 検查に熟知した回答が得られていることから，主体的に 検查に関与する診療放射線技師か放射線科医からの回答 が多くなされていると予想される ${ }^{13)}$.

本研究では, 決定木分析により消極的配置の背景要因 を抽出し, 続いて抽出された非電離放射線/身体負荷の 見解が選択に与える影響についてロジスティック回帰分 析により検討を行った. データの信頼性に関しては決定 木分析の正分類率は実施した3段階いずれの段階におい ても消極的配置が 90.7-92.7\%，ロジスティック回帰分 析においては判別的中率は $91.2 \%$ であり, 十分信頼性が あるものと考えられる.

本研究で着目した非電離放射線の見解に関しては, 非 電離放射線のリスク認識という概念として携帯電話や送 電線に関するリスクコミュニケーション研究の中で研究 例がある ${ }^{17}$. 例えば，携帯電話を対象とした非電離放射 線のリスク認識に関する研究では, リスク認識の増大は 個人の知識レベルの上昇が関与するという報告があ る ${ }^{17)}$. このため, 本研究においても同様の傾向があるの ではと推測し, 回答背景にある非電離放射線に対する関 心や知識取得状況の影響について検討を行った結果, 第 一段階の決定木分析において「関心・知識取得」が要因 として抽出されたが（図1），ロジスティック回帰分析 においては有意差は観察されなかった（表3)。これは 関心や知識取得状況よりオッズ比の変化が大きい要因 （最も大きい「有害性の懸念」など）がより選択に貢献 している可能性が考えられる. ただし, 本研究の限界点 として知識の内容や正確さを直接訊ねる設問がないた め, 今後知識取得状況と内容の関連については精査する 必要があると考えられる.

一方で，リスク認識自体，すなわち非電離放射線の有 害性に対する懸念は, 消極的配置の選択において強く影 響し保守的傾向でその影響がより強く観察された (表3). 非電離放射線, 特にMRIにおいて最も懸念され る静磁場については現在のところ明確な影響の報告はな い状況であり ${ }^{5-8)}$, 単純集計では有害性に対する明確な 懸念を有する回答者（3.9\%）よりも念のための措置を 必要と考える回答者 $(57.6 \%)$ が多く存在することか $丂^{13)}$, 非電離放射線（特に静磁場について）, 発生・生 
殖に対し潜在的にリスクが不明とみなしている層が多い と考えられる.「興味・知識取得」の結果とあわせて考 えると, 非電離放射線に対し興味関心があり情報に対し 接触をしていても, 非電離放射線の有害性に対する情報 を明確に提示しない限りは配置に対する考え方は変化が ないと考えられるため, そのような背景要因を重視した 安全情報の提供が求められていると考えらえる.

非電離放射線について明確な有害性の報告がないもの のリスクが不明とみなす考え方については，MRI検查 業務に従事する就業者の作業安全に対する普段の認識を 反映している可能性がある. 実務上では, MRI装置か らの漏洩磁場による強磁性体の吸着は深刻な受傷につな がる恐れがあるため, MRI検査業務に携わる就業者は 患者安全の立場から静磁場が発生していることについて 常に意識をしていると推測される. 我々の先行研究で MRI 検査業務の安全性に関する調査を診療放射線技師, 臨床検査技師など他職種合同で実施した結果，必ずしも 全員がMRI検查に関与する立場でないにもかかわらず 診療放射線技師は他職種より有意にMR安全に関するス コアが高かった ${ }^{18)}$. また, 因子分析の結果からは静磁場 に関する得点が高く，他職種においてもその傾向はみら れるものの, 診療放射線技師では更にハードウェアや非 電離放射により生じる患者の熱傷に対する安全対策 （MR適合性）などについても全体的に得点が高かっ $た^{18)}$. 今後, 作業環境の安全意識と非電離放射線リスク 認識をより直接的に諮る調査を行うことで, リスクが不 明とみなす要因が明確になると考えられる。

本研究では作業環境に関連する項目として「ばく露防 護」と「身体負荷」の項目が決定木分析で抽出され（図1), ロジスティック回帰分析でも消極的配置の回答に影響す る要因であった（表3)。「ばく露防止」に関連して調査 票ではMRI装置からの漏洩磁界に関する設問を設けて いる，設問では，「漏洩磁界マップを保有し，ガントリ 付近の漏洩磁界も把握している」という回答は $12.6 \%$ で あり, 大多数は $5 \mathrm{G}$ ライン（漏洩磁界が $0.5 \mathrm{mT}$ となる 地点の表示: 機器の誤作動防止や吸着事故防止のため制 限区域を明示するもの) のみ把握している (21.7\%) か, 意識していない (49.7\%) という回答であった ${ }^{13)}$. 磁界 勾配が急峻な部分ではめまい・ふらつきを生じさせる可 能性があることから $\left.\left.{ }^{1)}, 14\right), 15\right)$, 妊娠就業者の転倒を防ぐ ためにも漏洩磁界マップについて確認をとることは必要 と考えられる. また, 身体負荷の見解についても考慮要 素であることが示されたため, 身体負荷低減の具体的手 段（例：スライダーの使用など）も情報提供に含めるこ とでより包括的な判断に役立つと考えられる.

我々の報告ではMRI検查業務に関与する女性比率は 中央值（0を除く）で $33.3 \%$ と女性の登用が進んでい る ${ }^{13)}$.このため, 弤娠・出産というライフイベントと共 生する働き方に扔いて，管理者と当事者が非電離放射線 や身体負荷に対する見解を十分話し合い方針を決定する ことが求められるが，その場面において双方が同程度に 安全情報を共有できる資料を提供することが必要であ
る. 現在解析中の他の二方針（積極的配置，現状維持） においても, 非電離放射線/身体負荷の見解が方針選択 の背景要因であることが示唆されていることから, 安全 性資料作成においてはこれら要因に関する言及が必要と 考えられる. 本研究の結果は安全性資料作成の際にこれ ら要因に着想した経緯の説明材料となりうる. しかしな がら, 配布に際しては本調査の回答率は約 $37 \%$ でる ことからもMRI検査の安全について全ての施設が高い 意識を持っているとは限らないことを考慮し, 不参加施 設を含む国内の MRI施設に広く行きわたる安全啓発手 段（例：ウェブを通じた発信など）を検討する必要があ ると考えられる。

\section{5 結論}

本研究では, 妊娠就業者の MRI検査業務配置におけ る消極的配置の選択において, 非電離放射線 /身体負荷 が与える影響についてロジスティック回帰分析と決定木 分析により検討を行った．決定木分析では非電離放射線 /身体負荷の見解が関連の強い要因として抽出され, 特 に有害性に関する見解が第一層に抽出された．ロジステ イック回帰分析での結果からは, 非電離放射線の有害性 の懸念に関する見解が最も選択に影響していた。 また, 身体負荷の見解についても配置方針を検討する際の考慮 要素であることが示唆された.

\section{6 謝辞}

本研究は一般社団法人 日本磁気共鳴医学会, 公益社 団法人 日本診療放射線技師会, 公益社団法人日本放 射線技術学会, 公益社団法人 大阪府診療放射線技師会, 公益社団法人 宮城県放射線技師会の 5 団体との共同事 業で実施した. 公益社団法人 日本放射線技術学会は調 查票配布後にご協力いただいた．本研究は独立行政法人 労働者健康安全機構 労働安全衛生総合研究所運営費交 付金で実施する特別研究「医療施設の非電離放射線ばく 露に関する調査研究（P-29-01）」により行った. また, 決定木分析については東北大学文学部 言語学研究室の 木山幸子准教授より技術的助言を受けた。

本調査を実施するにあたりご支援をいただき，また調 查票作成にご協力いただいた有志の方々に厚く御礼申し 上げます。

\section{文献}

1) International Commission on Non-Ionizing Radiation Protection. ICNIRP guidelines on "LIMITS OF EXPOSURE TO STATIC MAGNETIC FIELDS”. Health Physics 2009; 96 (4):504-514.

2) International Commission on Non-Ionizing Radiation Protection. ICNIRP guidelines for "LIMITING EXPOSURE TO TIME-VARYING ELECTRIC AND MAGNETIC FIELDS (1HZ-100 kHZ)". Health Physics 2010; $99(6): 818-836$.

3) International Commission on Non-Ionizing Radiation 
Protection. ICNIRP guidelines for "FOR LIMITING EXPOSURE TO TIME-VARYING ELECTRIC, MAGNETIC AND ELECTROMAGNETIC FIELDS (UP TO 300 GHZ)". Health Physics 1998; HEALTH PHYSICS 74 (4):494-522.

4) International Electrotechnical Commission (IEC) 606012-33, 2010, Amd 2 in 2015.

5) Temperton DH, Pregnancy and Work in Diagnostic Imaging Departments. 2nd Ed. British Institute of Radiology 2008; 1-17.

6) Expert Panel on MR Safety et al., ACR Guidance Document on MR Safe Practices: 2013. Journal of Magnetic Resonance Imaging 2013; 37:501-530.

7) Kanal E, Gillen J, Evans JA, Savitz DA, Shellock FG. Survey of Reproductive Health among Female MR workers. Radiology 1993; 187(2):395-399.

8) World Health Organization, Environmental Health Criteria 232 Static Fields. 2006; 1-351.

9) Ray JG, Vermeulen MJ, Bharatha A, Montanera WJ, Park AL. Association Between MRI Exposure During Pregnancy and Fetal and Childhood Outcomes. JAMA 2016; 316(9):952-961.

10) World Health Organization, 2006 WHO Research Agenda for Static Fields. 2006; 1-6.

11) International Commission on Non-Ionizing Radiation Protection. ICNIRP statement on "DIAGNOSTIC DEVICES USING NONIONIZING RADIATION: EXISTING REGULATIONS AND POTENTIAL HEALTH RISKS". Health Physics 2017; 112(3):305-321.

12) Yamaguchi-Sekino $S$, Nakai $T$, Imai $S$, Izawa $S$, Okuno $T$.
Occupational exposure levels of static magnetic field during routine MRI examination in 3T MR system. Bioelectromagnetics. 2014; 35(1):70-5.

13）山口さち子, 井澤修平, 前谷津文雄, 土`井 司, 引地健生, 藤田秀樹, 今井信也, 赤羽 学, 王 瑞生. 本邦におけ る妊娠中の MRI検査業務担当の現況と非電離放射線（静 磁場ばく露）の意識状況調査 概要報告. 磁気共鳴医学 会誌 2018; 38 (4):103-119.

14) International Commission on Non- Ionizing Radiation Protection. ICNIRP guidelines for " LIMITING EXPOSURE TO ELECTRIC FIELDS INDUCED BY MOVEMENT OF THE HUMAN BODY IN A STATIC MANGETIC FIELD AND BY TIME- VARYING MAGNETIC FIELDS BELOW 1Hz". Health Physics 2014; 106 (3):418-425.

15）山口さち子, 井沢修平, 原谷隆史, 今井信也, 奥野勉. MR 検査室での作業に関するアンケート調査. 労衝安全衛生 総合研究所特別調查報告 (SRR). 2014; 44:2-7.

16) Kass VG. An Exploratory Technique for Investigating Large Quantities of Categorical Data. Appl. Statist. 1980;29 (2): 119-127

17) Kim K, Kim HJ, Song DJ, Cho YM, Choi JW. Risk perception and public concerns of electromagnetic waves from cellular phones in Korea. Bioelectromagnetics. 2014; 35 (4):235-44

18）山口 さち子, 中井 敏晴. 医療系職員の磁気共鳴画像技術 の利用における安全意識調查. 労働安全衛生研究. 2014;7 (1):39-46. 


\title{
Analyses of background factors on allocating MRI scan duties to pregnant employees
}

by

\author{
Sachiko YAMAGUCHI-SEKINO*1, Humio MAEYATSU*2, Tsukasa DOI*3, Takeo HIKICHI*4 \\ Hideki FUJITA*5 $^{* 5}$, Shinya IMAI*6, Manabu AKAHANE*7, Shuhei IZAWA*8, Rui-Sheng WANG*1
}

In the previous study, we sent 5763 questionnaires to facilities equipped with MRI devices in Japan in order to survey policies on allocating MRI scan duties to pregnant employees. This study analyzed background factors in decision processes of allocation, in particular, a choice which represented a less-promoted allocation pattern before declaration of pregnancy. We focused on each respondent's view for non-ionizing radiation (NIR) and physical load in MRI scan duties as possible factors in decision processes. Decision tree and binomial logistic regression analyses showed that these factors closely connected with decision processes in less-promoted allocation. Especially, concerns of adverse health effects caused by NIR exposure were strong motivations in making a judge for pregnant employee's allocation.

Key Words: Non-ionizing radiation, MRI, Safety awareness, Risk communication

*1 Industrial Toxicology and Health Effects Research Group, National Institute of Occupational Safety and Health

*2 Public interest foundation Miyagi Kosei Association Izumi Hospital Radiology department

*3 Takai Hospital

*4 Hirose Hospital

*5 Osaka Saiseikai Nakatsu Hospital

*6 Faculty of Health Sciences, Butsuryo College of Osaka

*7 Department of Public Health, Health Management and Policy, Nara Medical University

*8 Occupational Stress Research Group, National Institute of Occupational Safety and Health 